\title{
NEWS OF RECENT ANTI-APARTHEID ACTIVITIES
}

Organizations planning anti-apartheid activities are encouraged to send information about their activities as well as useful information collected to the office of the News/etter.

\section{AFRICAN STUDIES ASSOCIATION CURRENT ISSUES COMMITTEE}

[The following letter and questionnaire was sent to 1,500 colleges and universities at the end of March 1978. The Committee on Current Issues would be grateful if ASA members at those universities would urge their universities to participate in this survey.]

February 6, 1978

\section{Dear Friend:}

Members of university and college communities have raised questions about the investment or other use of their institutions' funds by firms doing business with South Africa. The Current Issues Committee of the African Studies Association is undertaking a survey to determine the extent to which university and college funds have been made available for use by such firms. The results of the completed survey will be published either in Issue or the African Studies Newsletter, both publications of the Association.

We enclose a short list of the thirteen leading United States firms doing business in South Africa, and the banks which have been the primary participants in arranging loans to South Africa. Using that list, would you please complete the short questionnaire and return it to us in the enclosed envelope.

The African Studies Association is a non-profit organization of scholars and specialists in African affairs. I will be pleased to provide any additional information about the Association upon request.

Sincerely,

David Robinson

Chairperson

Current Issues Committee

\section{Short List of Leading U.S. Corporations and Banks Doing Business in South Africa}

Almost four hundred United States companies have investments in South Africa. A few have, however, played a leading role there. The National Council of Churches' Corporate Information Center, in a report entitled Church Investments, Corporations and Southern Africa, estimates that thirteen United States firms have supplied over three fourths of American capital invested there. These are:

Caterpillar
Chrysler*
Firestone
Ford
General Electric
General Motors

\author{
Goodyear \\ International Business Machines \\ International Telephone and Telegraph \\ 3M \\ Mobil Oil \\ Caltex (Texaco and Standard Oil of California) \\ Union Carbide
}

Five major American banks have played a leading role, especially in recent years, in arranging international loans which have helped South Africa to finance international purchases of strategic items including capital equipment and machinery, oil, and military supplies. These five banks are Citicorp, Chase Manhattan, Morgan Guaranty, Manufacturers Hanover, and the Bank of America.

*In 1976, Chrysler merged its South African subsidiary with Illings Motors, Ltd., a manufacturing firm owned by Anglo-American Corp., to form Sigma Motor Co. Chrysler retained 24.5\% of Sigma which has assets of $\$ 117$ millions. 


\section{QUESTIONNAIRE}

1. Concerning leading corporations with investments in South Africa:

a. Does your school possess stock certificates in any of the companies on the enclosed short list?

b. Is the percentage of your school's endowments in these stocks (check one):

less than $10 \%$ between 25 and $50 \%$ a

between 10 and $25 \%$ between 50 and $75 \%$ 口

over $75 \%$ व

c. Does the total cash value of these stocks represent (check one):

less than $\$ 1$ million $\square \quad$ between $\$ 10$ and $\$ 20$ million $\square$

between $\$ 1$ and $\$ 10$ million $\square \quad$ between $\$ 20$ and $\$ 50$ million $\square$

over $\$ 50$ million $\square$

d. Are you considering taking any action with respect to these stocks by

(1) selling them $\square$

(2) initiating or acting on resolutions on corporate responsibility $\square$

(3) other (please specify)

2. Concerning leading banks which have participated in major loans to South Africa:

a. Does your school keep any large amounts of funds, pensions, or trust monies in any of the five banks listed?

b. Are you considering

(1) withdrawing these funds

(2) raising issues of moral concern with these banks

(3) other action (please specify)

3. Comments:

\section{LETTER FROM THE INTERNATIONAL DEVELOPMENT PROGRAM CLARK UNIVERSITY}

Dear Mr/Ms.:

February 1978

As anti-apartheid activity is gaining momentum, both throughout the United States and the world, we, here at Clark University in Worcester, Ma., have begun a research project that will be incorporated and coordinated within the larger network of the Association of Concerned African Scholars (ACAS). Our contribution can be summarized in two parts:

A. to establish an index of contacts and resources for information of America's concerns in southern Africa, for people to utilize. As well as for research, it will include a list of films, speakers, organizations willing to participate in anti-apartheid campaigns.

B. to organize an up-to-date reveiw of current events in southern Africa as reported by the U.S. press. We see two purposes: first, as a resource for specific research; second, as a coherent, analytical history of the past few years.

We will try to trace the interconnections between the following as they affect southern Africa:

a. anti-apartheid activity in the U.S.

b. events in southern Africa

c. American foreign policy

d. multinational corporate business activity

e. public opinion, home and abroad

Since this project is still in its embryonic stages, we would like to know whether we are replicating the work done elsewhere. Also, we would appreciate any publications, information, contacts, suggestions, and/or advise that would assist this project, particularly on U.S. corporate involvements, corporate social responsibility, military action.

Although we have not started, our orientation is to focus on regional activity and research ways in which specific corporate and other involvements in southern Africa affect a particular region. By 
this, we feel, people should and would be informed as to why it is in their interest to know about southern Africa. For our part in a larger network, we are seeking information vis a vis Massachusetts state affairs and South Africa.

Thank you

Sincerely

Amy Novick

c/o Ann Seidman

International Development Program

Clark University

Worcester, Mass. 01610

\title{
LETTER FROM THE COMMITTEE FOR SOCIAL JUSTICE, CARLETON COLLEGE
}

To the African Studies Association:

Our committee is concerned with the violation of human rights in the United States and abroad. Currently, we are examining our stock portfolio with the specific aim of formulating responsible investment criteria. We are particularly concerned with college investments in corporations involved in South Africa-an issue which has sparked widespresd activity throughout many academic communities. There is a clear need to coordinate these individual efforts.

It has come to our attention that your organization is working on and concerned with this issue. If you have any helpful information, advice or support (particularly along the lines of investment criteria) which you would be able to pass on to our committee, we would be extremely grateful.

Sincerely,

Julie Criseitsello

Committee for Social Justice

Carleton College

Northfield, Minnesota 55057

\section{MIGHIGAN LEGISLATURE HOUSE CONCURRENT RESOLUTION NO. 462}

\author{
Offered by Representatives Vaughn and Bennane and Senator McCollough \\ A CONCURRENT RESOLUTION URGING THE CONGRESS OF THE UNITED STATES \\ AND THE PRESIDENT OF THE UNITED STATES TO IMPOSE
}

\section{SANCTIONS AGAINST THE SOUTH AFRICAN GOVERNMENT}

Whereas, The recent violations of human rights in South Africa in abrogating the freedom of expression of that country's black majority have raised the ire of decent people throughout the world who harbor and cling to a fervent belief in the dignity of man; and

Whereas, Certainly one of the most fundamental and essential commodities of any society is its freedom of the press. In the abolition and banning of freedom of the press, the South African government has stripped the people of one of their most precious rights; and

Whereas, The South African government, built upon the policy of apartheid, has long resisted efforts from the outside to implement a policy of racial equality. In fact, the South African government has done virtually nothing to decrease the growth of the suppression of men and women, despite pressures brought to bear by other countries, including the United States; and

Whereas, With the controversial death of a prominent black leader, the arrest of many important anti-apartheid blacks and whites, and the total dissolution of a free press, the South African regime has again flaunted its disregard for the inherent rights of human beings; and

Whereas, Several officials of the United States, including the United States Ambassador to the United Nations, have offered suggestions as to what real and effective measures can be taken as sanctions against the South African government. Courses of action that have been brought forth include a suspension of arms trade between the United States and South Africa, a ban on investments in South Africa, and curbs on trade with South Africa; and 
Whereas, Taking into account the President's avowed commitment to the cause of human rights, the immense respect of the American people for freedom, and the United States' role as a leader among the Nations of the world, the grave situation in South Africa demands swift and certain action by this country. It is, therefore, necessary for sanctions to be put into effect; now, therefore, be it

RESOLVED BY THE HOUSE OF REPRESENTATIVES (the Senate concurring), That the Michigan Legislature urge the Congress of the United States and the President of the United States to impose immediate sanctions against the South African government in response to that country's disregard for human rights and dignity; and be it further

RESOLVED, That copies of this resolution be transmitted to the President of the United States Senate, The Speaker of the United States House of Representatives, to each member of the Michigan Delegation to the Congress of the United States, the President of the United States, the Government of South Africa, and the United Nations.

Adopted by the House of Representatives, February 6, 1978.

Adopted by the Senate, February 8, 1978.

\section{INFORMATION PACKET FROM THE SOUTH AFRICA CATALYST PROJECT}

Cover Letter

Enclosed you will find an odd assortment of material you may find useful in working on South Africa. This mailing is by the South Africa Catalyst Project, funded by various foundations, and unaffiliated politically.

The enclosed petitions are in the hope of getting organizational and other key endorsements (elected officials etc.) from around the country for the use of the California campaign. Please return them to the Catalyst Project along with any queations or comments you might have on all this stuff. The only specifically Catalyst publications are the two booklets so marked. The other stuff comes from the various active groups in California.

The address list and comments on campuses are meant as a resource and shouldn't be taken personally if inaccurate. Just send us the correction.

South Africa has become the biggest issue since Viet Nam. There is more campus activity now than there has been since 1971 and the number of schools becoming active, and the growing activity at schools already involved, is extraordinary. All indications are that these trends will continue for some time. Have an active year.

Chris Gray

South Africa Catalyst Project 570 Oxford Street, No. E Palo Alto, California 94306

(415) $327-3947$

\section{[Petition circulated by the South Africa Catalyst Project]}

\section{STOP INVESTMENT IN SOUTH AFRICA}

This is a critical period in South African people's struggle against apartheid, a brutal system of legalized racism which maintains the rule of a white minority regime. U.S. corporations prop up and profit from this system, which keeps South Africa's black majority living in poverty with an income a fraction of that of whites.

The State of California has over $2 \frac{1}{2}$ billion dollars, derived from state employees' payroll deductions and tax revenues, invested in companies doing business in the Republic of South Africa. Of this sum 615 million dollars, largely employees' pension funds, is controlled by the Regents of the University of California. Most of the rest of the money comes from the California Public Employees' Retirement System and the State Teachers' Retirement System.

We, the undersigned, demand that the California State Legislature, the Governor, the Board of Pension Commissioners, and the UC Board of Regents withdraw our tax dollars, UC endowments, 
and pension funds from all corporations doing business in or with the Republic of South Africa.

As an alternative, we propose that these institutions reinvest our public funds to solve the problems of unemployment, hunger, housing, crime, education, energy, and the environment in the state of California.

\section{LIBERATION SUPPORT GROUPS AND OTHERS}

\section{[List circulated by the South Africa Catalyst Project]}

Bay Area Namibia Action Group

Stop Banking on Apartheid

Miloanne Hecathorn

450 30th Street

San Francisco, California 94131

(415) 824-1167

\section{People's Cultural Center \\ Roger \\ 721 Valencia}

San Francisco, California 94110

(415) 431-9329

Southern African Support Committee (SASC)

Vincent Perkins

816 Summit

Pasadena, California 91103

$684-1892$ or $577-0643$

\section{Liberation Support Movement \\ San Francisco, California \\ $635-4863$}

Int. Longshoremen's Union, Local 10

Bay Area, Bill Proctor

$841-5882$

Southern Bay Area African Support Committee Melody 655-1989

Selby 922-3495

Karabol (South African Student's Group)

Bay Area

848-3810

University Christian Movement

Bill Krumsky

First Church Congregational

11 Garden Street

Cambridge, Mass. 02138

617-354-6583

Interfaith Center for Corporate Responsibility

Tim Smith or Mike Clark

475 Riverside Drive

New York, New York 10027

212-870-2294(5)

American Committee on Africa

305 East 46th St.

New York, New York 10017

212-838-5030
Clergy and Laity Concerned 198 Broadway 3rd Floor

Gene Jones

New York, New York 10038

NIA-Cultural Organization 5053 Churchward St.

San Diego, California 92113

Greg Akili

(714) 263-2153

Coalition for the Liberation of Southern Africa Carol Collins

$615 \mathrm{~W}$. Wellington

Chicago, Illinois 60657

(312) $472-2107$ or $348-3370$

Liberation of South Africa Committee 130 Wellington Hill St. Suite 2

Mattapan, Mass. 02126

South Africa Solidarity Committee

Anne Crane

51 Chilton Street

Cambridge, Mass 02139

American Friends Service Committee

South Africa Program

2161 Mass Avenue.

Cambridge, Mass.

661-6130 (W)

$9930974(\mathrm{H})$

AFSC South Africa Program

Bill Sutherland, Carol Benta

1501 Cherry Street

Philadelphia, Penn. 19102

American Committee on Africa

(Bank Campaign)

Prexy Nesbitt or Jennifer Davis

305 East 46th Street

New York, New York

(212) $838-5030$

People's Independence Coalition

341 George St.

New Brunswick, New Jersey

United People's Campaign Against

Apartheid and Racism

Roz Pernell

Philadelphia, Penn.

843-1631 
Philadelphia Namibia Action Group

Ken Martin and Joan Pryor

(215) $972-7498$ or $474-9592$

The Washington Office on Africa

110 Maryland Avenue, N.W.

Washington, D.C. 20002

Madison Area Committee on Southern Africa 306 N. Brooks Street

Madison, Wisconsin 53715

(608) 256-7403
South Africa Catalyst Project

Chris Gray

570 Oxford St. No. E

Palo Alto, California 94306

(415) 327-3947

Zimbabwe Africa National Union

Leonard Muturanu

850 Stanyon, Apt. 5

San Francisco, California

285-1288

Pan African Congress (S.F.)

Gerald Motanny

San Francisco, California

848-2153

\section{CAMPUSES WORKING AGAINST AMERICAN COMPLICITY IN APARTHEID}

\section{[List distributed by the South Africa Catalyst Project]}

This information could easily be out of date-please send us up-dates.

Key:

Extensive protests and movement @

Significant Organizing *

Beginning Organizing ${ }^{\dagger}$

Don't Know?

\section{CALIFORNIA}

Stanford University @

U.C. Santa Cruz @

U.C. Davis *

U.C. Berkeley *

U.C.L.A. *

U.C. Santa Barbara *

U.C.S.D. *

U.C. Irvine $\dagger$

U.C. Riverside $†$

Cal State Northridge *

Cal State Fullerton $†$

Cal State Long Beach †

Cal State San Diego ?

Cal State L.A. ?

Cal State Humboldt ?

Cal State San Luis Obispo ?

Cal State Bakersfield?

Chapman College $†$

Occidental College *

Clairmont Colleges *

Palomar Jr. College?

Pasadena City College *

San Diego City College?

Grossmont Community College ?

Mesa Junior College?

\section{ARIZONA}

Arizona State University?

\section{CONNECTICUT}

Yale *

Wesleyan?

University of Connecticut?

\section{INDIANA}

Earlham College $†$

IOWA

Grinnel *

\section{NEW JERSEY}

Farleigh Dickenson College?

Princeton University *

Rutgers University *

\section{MICHIGAN}

University of Michigan *

Michigan State *

\section{NEW HAMPSHIRE}

Dartmouth?

\section{WISCONSIN}

University of Wisconsin *

MASSACHUSETTS

Harvard University *

Amherst University @ 


\section{U. Mass Boston?}

Northeastern University?

Holy Cross College?

Wellesley *

Boston University $†$

Clark University ?

Goddard-Cambridge School?

Brandeis *

Tufts $t$

Smith $\uparrow$

Mt. Holyoke?

\section{NEW YORK}

Columbia University *

Cornell *

Colgate-Rochester Divinity?

SUNY-Genesco?

Hobart and William Smith Colleges?

NYU Law?

SUNY-Buffalo?

SUNY-Binghampton?

\section{OREGON}

University of Oregon @

Oregon State?

Portland City College?
WASHINGTON

University of Washington?

WASHINGTON D.C.

Howard University ${ }^{\dagger}$

\section{OHIO}

Antioch College *

Ohio State?

Case Western †

\section{PENNSYLVANIA}

Swarthmore College?

University of Penn?

State College Penn?

Temple University?

Philadelphia Community College?

La Salle College?

\section{RHODE ISLAND}

Brown University?

University of Rhode Island?

\section{MARYLAND}

University of Maryland

\section{SIGNIFICANT RECENT EVENTS}

\section{[Fact Sheet distributed by the South Africa Catalyst Project]}

HAMPSHIRE COLLEGE-After a sit-in in May, 1977, Hampshire College divested.

UNIVERSITY OF MASSACHUSETTS-After a large scale campaign the University of Mass. voted to divest itself of its holdings in companies in South Africa. September 14, 1977.

UNIVERSITY OF OREGON-After extensive organizing and an overwhelming student referendum the State Board of Higher Education voted on November 6, 1977 bv 8 to 3 to divest. The divestment is being held up by legal hassles.

BRANDEIS UNIVERSITY-Half the students signed petitions for divestment this fall. On Nov. 22 the Trustees voted for a partial divestment of one or two companies that are in South Africa.

UNIVERSITY OF WISCONSIN-Long term organizing in Madison has resulted in City Council and County Board resolutions urging an end to business with U.S. corporations active in S.A. The State Attorney General's ruling that $U$ of $W$ must divest has been held up by the $U$ of $W$ regents.

STANFORD UNIVERSITY-The University has been given a Feb. 14 deadline to divest itself of holdings in $8 \mathrm{key}$ corporations active in S.A. by SCRIP, the group that led the sit-in of last May that resulted in 294 arrests.

UNIVERSITY OF CALIFORNIA - has launched a petition drive at all nine campuses with the aim of collecting 50,000 plus signatures by March 17th. A demand has been issued for the regents to come debate at all the campuses. Last year there were sit-ins at three U.C. campuses (Santa Cruz-401, Berkeley-56, and Davis-19) This year there is good organizing on all campuses.

CAL STATE NORTHRIDGE-A bovcott is underway against the cafeteria and vending machines that are controlled by a board that has significant investments in companies active in S.A. 
SMITH-has sold its holdings in a few corporations that sent unsatisfactory replies to letters from the college questioning them on their role in South Africa.

Please send information on actions to the Catalyst Project for distribution to all campuses and to: to: Politics and Education, Wesleyan Station, Fisk Hall, Jay Kilbourn and Joel Lefkowitz, Middletown, Conn. 06457 (203/347-9411, ext. 660) for publication in their journal. Information should also be sent to Prexy Nesbitt, American Committee on Africa, 305 East 46th Street, New York, New York (212/838-5030).

\section{CAMPUS CONTACTS FOR GROUPS WORKING ON DIVESTMENT FROM CORPORATIONS WITH HOLDINGS IN SOUTH AFRICA}

[Distributed by the South Africa Catalyst Project]

\section{CALIFORNIA}

U. of California-Davis

Nancy Jordon

923 3rd St.

Davis, CA 95616

(916) 758-1991

Dallas Burtraw

816 K St.

Davis, California 95616

(916) 758-4584

U.C.-Berkeley

Carol Bremner 2600 Ridge Road

Berkeley, CA 94709

(415) $845-4710$

Diane Kolodny

2249 Parker

Berkeley, CA

(415) 548-9264

UC Santa Cruz

People For A Free South

Africa

Marc Bertel

119 Highland St.

Santa Cruz, CA 95060

Stew Lawrence

431 Mary Ave

Santa Cruz, CA 95060

(408) 427-0611

\section{UC Santa Barbara}

Trebor Fullwood

6593 Sabado Tarde

Isla Vista

(805) 968-0291

UC Los Angeles

Geoffrey Goshgarion

3102 No. 4 Sawtelle

Los Angeles, CA

(213) 398-1358
Mike Davis

512 Midvale

Los Angeles 90024

(213) $478-2127$

UC Riverside

Bob Lawrence and

Edward Taylor

3281 Chestnut St.

Riverside, CA 92501

784-0136

Cal State L.A.

Rose Katz

128 S. Clark Dr.

Los Angeles 90078

U.C. Irvine

Miles Mendehall

515 Emerald Bay

Laguna Beach, CA

(714) $494-3818$

Dave Wheeler

204 Amethyst

Balboa Island, CA 92662

(714) 673-2878

UC San Diego

Martin Gran

Hoppy Chandler

Chris D'Arpa

6548 Radcliffe Dr.

San Diego, CA

(714) $455-1674$

\section{Stanford University}

Chris Gray

Chris Coleman

Anne Henkels

570 Oxford Street, No. E

Palo Alto, CA 94306

(415) 327-3947

South Africa Catalyst Project
Lloyd Dixon

Columbae House

549 Lasuen St.

Stanford, 94305

(415) $321-8868$

California State Northridge

Todd Davis

8150 Chastain Ave.

Reseda, CA

(213) 342-0856 or

885-2477

Jim Roofer

(213) 344-0531

\section{Cal State Fullerton}

Wayne Hin':el

510 Plantation PI.

Anaheim, CA 92806

(714) 630-0726

\section{Cal St. San Luis Obispo}

Laurie Kershner

738 Grand No. 5

San Luis Obispo, CA 93401

Cal. State Long Beach

Tony Wolfe

c/o United Campus Ministry

Desk

Student Union

Long Beach, CA 90840

Cal State San Diego

Joe Davis

Black Student Union

(714) $286-6533$

Lawrence Swill

425-1281 ext. 226

Steve Glaser

(714) 286-6571 
Clairmont Colleges

Robert Keith

(213) 626-8521 x3089

Arthur Pinkey

(213) 624-3253

John Gallaher

(714) 626-8521 ×2525

\section{Occidental College \\ Rick Cole \\ 1320 Summit Ave. \\ Pasadena, CA 91103 \\ (213) 794-3760}

\section{Chapman College \\ Rita Brock \\ c/o Chaplain's Office \\ 333 N. Glassell St. \\ Orange, CA 92666}

Polomar Junior College

Chris Fry

745.8505

\section{Pasadena City College}

Isaac Rehard

Pan African Student Assoc.

449-6661

\section{Humboldt State University \\ Walter C. Jenkins \\ 4480 Central Ave. \\ McKinleyville, CA 95521}

\section{ARIZONA}

\section{Arizona State University}

Connie Dunphy

1101 E. Apache Blvd. No. 20

Tempe, Arizona 85282

\section{COLORADO}

Cheryl Plumley

1224 S. Harrison

Denver, Colorado 80210

\section{CONNECTICUT}

Yale

Alex Wollcott

3047 Stiles

New Haven, Conn.

(203) 432-3047

Fred Rose

Anti-Apartheid Coalition

P.O. Box 154

Yale Station

New Haven, Conn 06520
Jessica Gordon

Black Student Alliance

Yale University

Afro-Am. Cultural Ctr.

211 Park St.

New Haven, Conn. 06520

\section{Wesleyan}

Frances Sheehan

Box 0977

Wesleyan Station

Middletown, Conn. 06457

University of Connecticut

Ben Magubane

Anthropology Dept.

University of Conn.

Storrs, Conn.

(203) $486-4514$

\section{INDIANA}

\section{Earlham College \\ Ann Rawlings \\ Box E 978 \\ Richmond, Indiana 47374}

\section{IOWA}

\section{Grinnell College \\ James Stuart \\ 1215 Park Street \\ Grinnell, lowa 50112 \\ 236-6181 ext. 277}

\section{MASSACHUSETTS}

Northeastern University

Afro-American Union

40 Leon St.

Boston, Mass

(617) 437-2200

\section{Harvard University}

Nina Seidman

Adams B-21

Harvard University

Cambridge, Mass. 02138

(617) 498-2037

Cindy Ruskin

Dunster House H 43

945 Memorial Drive

Cambridge, Mass. 02138

(617) 498-2271

Holy Cross College

Black Students Union

Worcester, Mass. 01610
Wellesley

Matie Gunnier

Wellesley College

Wellesley, Mass. 02181

(617) 237-2647

\section{Boston University}

Felix Zychlis

Bruce Stallsmith

20 Ashford St.

Allston, Mass. 02134

254-6613

Eddie Chevarez

394 Riverway St.

Boston, Mass. 02115

277-0645

\section{Clark University}

Jerome Rubin

Clark University

950 Main St.

Worcester, Mass.

(617) 757-3145

Goddard-Cambridge School of Social Change

South Africa Program

Rehka or Lasar

186 Hampshire Street

Cambridge, Mass.

Hampshire College

Joel Saxby

Carol Bengelsdorf

Box 1163

Amherst, Mass.

(413) 549-4600 ex. 238

Brandeis University

Dave Ratgrok

6 Wellington

Waltham, Mass. 02154

893-1563

Carl Rupert

Brandeis Committee to

Divest from South Africa

Box 2888

Waltham, Mass. 02154

Tufts University

Mark Niedergang

Tufts Political Action Group

Eaton Lounge

Tufts Univeristy

Medford, Mass. 02155 


\section{MICHIGAN}

University of Michigan

John Powell

University of Michigan

Community Services

2204 Michigan Union

Ann Arbor, Michigan 48109

(313) $763-2548$

Mighigan State University

Jim Thomas

Department of Sociology

Southern Africa Liberation

Committee

East Lansing, Michigan 48824

Dave M. Partidge

8171 Webster Road

Clio, Michigan 48420

\section{MINNESOTA}

Susan Ode

235 Amherst

St. Paul Minn. 55105

699-0374

\section{NEW JERSEY}

Fairleigh Dickenson Univ.

Mark Medoff

c/o Gauntlet

1000 River Road

Teaneck, New Jersey 07666

\section{Princeton University}

Marsha Bonner

Third World Center

Princeton, New Jersey 08540

(609) 452-0217

(609) $452-5494$

Adhimu Changa

Room 245 Lourie Lone

Princeton University

(609) 452-7864

(609) $452-5494$

\section{Rutgers University}

Terry Mead

Andor Skotnes

New Brunswick Coalition in

Solidarity with Southern

African Liberation

New Brunswick, New Jersey

(201) 297.6077

\section{NEW YORK}

Columbia University

Alfred Sears
Caribbean Students at

Columbia

314 Ferris Booth

New York, New York 10027

(212) $865-3382$

\section{SUNY-Genesco}

Dr. Barbara Joshi

Department of Political

Science

SUNY-Genesco

Genesco, New York

Cornell

Neil Getnick

112 Stewart Ave.

Apt. 3

Ithaca, New York 14850

(607) 273-7221

Colgate-Rochester Divinity

Dr. Gai Wilmore

Professor of Black Theology

(716) $271-1320$

\section{Columbia University}

Lee Cokorinos

Socialist Action Community

825 West End Ave. No. 5D

New York, New York 10025

(212) 866-2416

Crispin Gregorie

(212) 865-1037

Dave Grad

(212) 850-6421

Hobart and William Smith

College

Dunbar Moodie

Sociology Dept.

Geneva, New York

NYU Law

Liz Gonzalez

206 W. 106th St. No. 44

New York City 10025

(212) 865-9308

\section{SUNY-Buffalo}

Lawrence A. Perot

Students for Responsible

Research

8 East Depew, Apt. 3

Buffalo, New York 14214

Anthony Bonfeglio

75 Prospect Park West

Brooklyn, New York 11215
Frederick Douglass Ashanti

P.O. Box 278

Ridge, New York 11961

SUNY-Binghamton

Steve Smith

66 Colfax Ave.

Binghamton, N.Y. 13905

NORTH CAROLINA

Barbara McCoy

Box 19813

NCCU

Durham, N.C. 27707

\section{OHIO}

Antioch College

Antioch Coalition Against

Apartheid

Yellow Springs, Ohio 45387

Case Western

Seth Foldy

2232 Elandon Dr.

Cleveland Hts., Ohio 44106

(216) 229-7328

Ohio State University

Eric A. Schwing

National Student Coalition

Against Racism

55 East Patterson

Columbus, Ohio 43201

\section{OREGON}

\section{University of Oregon}

John Barlow

Associated Students of

Univ. of Ohio

Suite 4, Ground Floor

Eugene, Oregon 97403

Colette Postol

People for Southern African

Freedom (PSAF)

1345 Ferry

Eugene, Oregon 97401

(503) 342-6975

\section{PENNSYLVANIA}

Swarthmore College

Jane Holska

Tim Oberst

Jennifer Hayes

Swarthmore, PA 19081

Swarthmore exts. $279 \& 291$ 
University of Pennsylvania

Ernie Wilson

Dept. of Pol. Science

243-6325

Mary Hoover

Dept. of Education

2437113

State College P.A.

Brent Wissick

600 W. College Ave.

State College, P.A. 16801

(814) 273-3996

\section{Temple University \\ Pan African Studies \\ Tran Van Din}

\section{Philadelphia Community}

College

Ken Wharton

Operation Namibia

\section{La Salle College \\ Bert Streib \\ 843-0957}

WASHINGTON D.C.

\section{Howard University}

James Garreti

Dept. of Political Science

We also know the following schools are organizing on S.A., but we don't have their addresses: Univ of Maryland; Amherst University; U. Mass Amherst; U. of Washington; Oregon State; Portland City College (Oregon); San Diego City College; Grossmont Community College; Mesa Junior College (San Diego); Smith College (Mass.). Please send addresses to the Catalyst Project, so these institutions can be added to the mailing list.
Carolyn Wright

1350 E. St. N.W. Rm. 406

District Bldg.

Washington, D.C. 20004

727-1375

\section{WISCONSIN}

Professor Daniel P. Kunene

African Studies Program

University of Wisconsin

1456 Van Hise Hall

Madison, WI

(608) 262-2487

Professor Robert Dundon

Agricultural College

Soil Sciences

(608) 263-4190

Clarence Kailin

Madison Area Committee

on Southern Africa

306 N. Brooks St.

Madison, WI 53715

(608) 256.7403

Allan Quint

305 N. Frances St.

509 B West

Madison, Wisconsin 53703

\section{VIRGINIA}

Jane Lynn

10S. Blvd. No. 4

Richmond, VA 23220

\section{RHODE ISLAND}

Brown University

Garry Hicks

Box 5904

Brown Univ.

Providence, R.I. 02912

(401) 863-2120

(401) 863-3137

University of R.I.

Richard Lobban

Dept. of Anthropology

Univ. of R.I.

Providence, R.I.

\section{NEW HAMPSHIRE}

Prof. Hoyt Alverson

Dept. of Anthropology

Dartmouth College

Hanover, N.H. 03755

(603) 646-3257

\section{LETTER FROM THE TENNESSEE COALITION AGAINST APARTHEID}

Tennessee Coalition Against Apartheid

Box 24141

Nashville, Tennessee 37202

(615) 297-5104

African Studies Association

Brandeis University

Waltham, Mass. 02154

February 23, 1978

The South African tennis team is currently scheduled to play in the Davis Cup matches at Vanderbilt University in Nashville, Tennessee, March 17-19. This is in violation of the internationally sanctioned sports boycott of South Africa in sports currently endorsed by the United Nations and Organization of African Unity. The event has already received the condemnation of innumerable organizations and individuals in the United States and throughout the world.

The objective of the Tennessee Coalition Against Apartheid is to unite all who want to protest these matches and thus help isolate apartheid. This is of special significance since this can be the first massive demonstration against apartheid in the United States. It is in the interests of all organizations and individuals who would like to see the anti-apartheid movement take on a new mass character to 
protest these matches and seriously consider making building these demonstrations a priority for the next three weeks. This may break the political ice and allow the anti-apartheid movement to enter the mainstream of U.S. political life thus providing the potential for isolating apartheid in all spheres.

WE THEREFORE ISSUE AN URGENT NATIONAL CALL TO ALL WHO WANT TO PROTEST

THE PARTICIPATION OF THE SOUTH AFRICAN TENNIS TEAM IN THE DAVIS CUP MATCHES MARCH 17, 18, and 19. Contact the Coalition to endorse this demonstration effort.

The general strategy of the Coalition is to unite all political forces despite diversity to protest the matches and mobilize as many citizens as possible to show the sponsors of the Davis Cup (Vanderbilt University, United States Tennis Association, Davis Coal Inc., the Nashville Chamber of Commerce) and the people of the U.S., Azania (South Africa) and the world that Americans oppose apartheid and will not tolerate the use of a sporting event to sugar coat apartheid without a powerful nationally and internationally visible protest.

Building toward this demonstration we encourage all who have resources capable of assisting in education, agitation and mobilization of people from all over the nation to contact us and help us in this effort.

A copy of the Tennessee Coalition Against Apartheid's principles of unity is enclosed. But we do not seek as a priority endorsement of these principles. We would appreciate such an endorsement where possible. BUT WE SEEK AS A PRIORITY ENDORSEMENT OF THE PROTEST DEMONSTRATIONS, ESPECIALLY THE MARCH 18 PROTESTS. The March 18 demonstration is currently being spearheaded by the Coalition for Human Rights in South Africa and will be the largest.

Currently we seek immediate support in:

1. Broadcasting the call for this series of protests to the largest number of organizations and individuals through mailings and media available to the anti-apartheid movement. Everyone must take the initiative.

2. Help us educate the people in our immediate locale so thousands of Tennesseans can be mobilized. National educational resources would help.

3. Provide speakers, educational literature, films, volunteers, and funds to build for a legal but spirited series of protests March 17, 18 and 19.

4. We appeal for the mobilization of tens of thousands from around the nation and especially the Southern and border state region. Primary emphasis is on the 18th but support on the 17 th and 19 th is also wanted.

History provides us with this opportunity to help isolate the South African police-state. Unity is necessary whatever political differences may exist in the anti-apartheid movement. Specifics of the protests and educational work will be released to those interested. We will be close to the site of the matches as well as have facilities to accomodate tens of thousands of demonstrators. We will help provide a platform for anti-apartheid speakers from all sectors of the anti-apartheid movement. Help us isolate apartheid South Africa! Contact us immediately!

David Huet-Vaughn, Coordinator Tennessee Coalition Against Apartheid

\section{PRINCIPLES OF UNITY \\ TENNESSEE COALITION AGAINST APARTHEID}

TCAA HAS FORMED IN ORDER TO:

1. Educate the people of Tennessee about the cruelty and oppression of apartheid.

2. Deepen appreciation and support for the liberation struggles against white supremacist governments in Southern Africa.

3. Help coordinate nonviolent political actions to oppose supporters of and support for apartheid by the United States government and multinational corporations as well as international and national financial institutions.

TCAA supports the right of the peoples of Southern Africa to determine their own future. We recognize the Pan Africanist Congress and the African National Council as the voice of the South African people as do the United Nations and Organization of African Unity.

TCAA supports the internationally sanctioned sports boycott of South Africa.

TCAA supports the just demands of the liberation movements in South Africa for all governments to end military, economic, intelligence and political support for the fascist regime.

TCAA demands the total withdrawal of all United States corporations from South Africa. 
We seek to unite as many people and organizations as possible to effectively oppose and defeat apartheid.

\section{MEETINGS-PAST \& FUTURE}

The Search for Roots: The Jewish and African Experiences. Columbia School of International Affairs, New York City (November 20, 1977). Sponsored by the World Jewish Congress, Africa-Asia Office and the Columbia Institute of African Studies. Further information on the conference may be obtained from Susan Gitelson, World Jewish Congress, 15 East 84th Street, New York, New York 10028.

Third World Women and Development Conference. Marian College Library, Indianapolis, Indiana (March 2-3). For further information, write: The Indiana Consortium for International Programs, Manchester College, Box 137, N. Manchester, Indiana 46962.

International Colloquium on the Middle East and the United States-Perceptions and Policies. The Shiloah Center for Middle Eastern and African Studies, Tel Aviv University, Tel Aviv, Israel (March 23-27). Contact: Ms. Amira Margalith, Executive Secretary, Colloquium on the Middle East and the United States, Shiloah Center, Tel Aviv University, Tel Aviv, Israel.

Symposium on Black Community Control. Boston University Afro-American Studies Center, Brookline, Massachusetts (March 30). Historical examples: Liberia, Nova Scotia, Kansas and the Maroons. Papers by: Svend Holsoe (University of Delaware); Gwendalyn Wade (Texas Research Institute of Mental Science); Thomas Cox (Middlebury College); John Henrick Clarke (Hunter College). Contact: Adelaide Cromwell Gulliver, Afro-American Studies Center, 138 Montfort Street, Brookline, Mass. 02146.

Focus on South Africa: A Symposium at Carleton. Carleton College, Northfield, Minnesota March 31-April 1). Conference funded by the Minnesota Humanities Commission and supported by the National Endowment for the Humanities. For information, write: Focus on South Africa, Carleton College, Northfield Minnesota 55057.

Tenth Annual Conference of the Liberian Studies Association. Boston University, Boston, Mass. (April 6-8). Further information may be obtained from Thomas E. Hayden, Adademic Dean, Maryknoll Seminary, Maryknoll, New York 10545.

Second Annual NDEA Seminar on Foreign Area Studies. Columbia University, New York City (April 7-8). This is a two-day conference to review research frontiers in area studies along with the strategies and techniques for teaching area studies. The conference is particularly designed to emphasize issues and raise questions relevant to area studies programs at the small college. For further information, write: Area Studies Conference, Room 1303 International Affairs Building, Columbia University, New York, New York 10027.

Southern Anthropological Society Annual Meeting. Hyatt Regency Hotel, Lexington, Kentucky (April 12-15). Theme: "Predicting Sociocultural Change." Program Co-Chairs: Susan Abbott and John van Willigen, Department of Anthropology, University of Kentucky, Lexington, Kentucky 40506.

American Association of Physical Anthropologists Annual Meeting. Toronto, Canada (April 12-15). Program Chair: Daris R. Swindler, Department of Anthropology, University of Washington, Burke Museum Room 5, Seattle, Washington 98195.

Annual Conference on Ethnic and Minority Studies. University of Wisconsin, La Crosse (April 19-22). Theme: "Minority Women and Ethnicity."Write: George E. Carter, Director of Minority Studies, 101 Main Hall, University of Wisconsin, La Crosse, Wisconsin 54601.

African Heritage Studies Association Tenth Annual Meeting. Statler Hilton Hotel, New York City (April 20-23). Theme of the conference: "A Decade of Activity and Analysis in the African Diaspora: Clarification, Direction and Assessment." For additional information, contact: African Heritage Studies Association, c/o Black Studies Department, Goethals Hall, Room 107, City College, 138th Street and Convent Avenue, New York, New York 10031. Telephone: (212) 690-8117.

Western Social Science Association Annual Meeting. Hilton Hotel, Denver, Colorado (April 27-29). Program Chair: Reed Black, Department of Sociology, Brigham Young University, Provo, Utah 86402.

New York African Studies Association Fifth Annual Meeting. Kellogg Conference Center, Columbia University, New York City (April 28-29). Write: Phillips Stevens Jr., Department of Anthropology, SUNY-Buffalo, 4242 Ridge Lea Road, Amherst, New York 14226. 